\title{
A Comparative Study on the Corrosion Behaviour of Gas Nitrided and TiAlN Coated AISI D2 Steel by Thermo-Reactive Diffusion Technique
}

\author{
O. CEGIL ${ }^{a, *}, \mathrm{U} \cdot \mathrm{SEN}^{b}$ AND S. SEN ${ }^{b}$ \\ ${ }^{a}$ Department of Metal Education, Institute of Arts and Sciences, Sakarya University, 54187 Sakarya, Turkey \\ ${ }^{b}$ Department of Metallurgical and Materials Engineering, Engineering Faculty, Sakarya University \\ 54187 Sakarya, Turkey
}

\begin{abstract}
In this study, the corrosion behaviors of nitride and titanium aluminum nitride (TiAlN) layers deposited on AISI D2 steel samples are reported. Steel was at first nitrided in a nitrogen and ammonia atmosphere at $575^{\circ} \mathrm{C}$ for $8 \mathrm{~h}$ and then titanium nitride coating treatment was performed in the powder mixture consisting of ferro-titanium, aluminum, ammonium chloride and alumina at $1000^{\circ} \mathrm{C}$ for $2 \mathrm{~h}$ by thermo-reactive diffusion technique. Phase analysis and corrosion tests were realized on the titanium aluminum nitride coated steel. The corrosion properties of uncoated and coated samples were characterized by potentiostatic polarization test. The tests were conducted using a three-electrode system test unit with a platinum counter electrode of $2.269 \mathrm{~cm}^{2}$ and an $\mathrm{Ag} / \mathrm{AgCl}, 3 \mathrm{M}$ $\mathrm{KCl}$ electrode as the reference electrode. Nitrided and TiAlN coated steel specimens exhibited higher corrosion resistance than uncoated steel in $0.5 \mathrm{M} \mathrm{H}_{2} \mathrm{SO}_{4}$ solution. Conclusively, the application of nitride and TiAlN films on AISI D2 steel increased surface hardness and corrosion resistance. TiAlN coating exhibits the highest corrosion resistance.
\end{abstract}

DOI: $10.12693 /$ APhysPolA.123.265

PACS: 81.05.Je, 81.65.Kn

\section{Introduction}

The nitriding process, first developed in the early 1900 s, continues to play an important role in many industrial applications. Along with the derivative nitrocarburizing process, nitriding often is used in the manufacture of aircraft, bearings, automotive components, textile machinery and turbine generations systems [1]. Transition metal nitrides are used as hard surface coatings. They also play a role in steels. In recent years, transition metal nitrides like TiN, $\mathrm{ZrN}$, TiAlN, NbN, TaN, and VN were successfully used as protective coatings in many fields for their high wear resistance, hardness and low friction coefficient characteristics [2-5].

Titanium aluminium nitride (TiAlN) has been developed as an alternative coating material since the 1980s. It was demonstrated that the hardness increased with $\mathrm{Al}$ content until a certain point because $\mathrm{Al}$ atoms with smaller ionic radius substituted for $\mathrm{Ti}$ atoms in $\mathrm{TiN}$ while keeping the $\mathrm{NaCl}$ structure. TiAlN has been commercially very successful due to significantly improved oxidation resistance and hardness over TiN. The corrosion behaviour of coatings of the type AlN and TiAlN has been, however, the subject of less exhaustive investigation [6-12].

This paper concentrates on the evaluation of the corrosion resistance of uncoated, nitrided steel and TiAlN coatings deposited on AISI D2 cold work tool steel by thermo-reactive diffusion (TRD).

\footnotetext{
*corresponding author; e-mail: ozkancegil@yahoo.com
}

\section{Experimental procedures}

The steel used for the nitro-titanizing treatment was AISI D2 steel which consisted of $1.54 \% \mathrm{C}, 0.28 \% \mathrm{Si}$, $0.29 \% \mathrm{Mn}, 0.023 \% \mathrm{P}, 0.005 \% \mathrm{~S}, 11.3 \% \mathrm{Cr}, 0.74 \% \mathrm{Mo}$, $0.77 \% \mathrm{Ni}, 0.74 \% \mathrm{~V}$ and iron (balance). The samples to be coated were machined as coupons to the dimensions of $20 \mathrm{~mm}$ in diameter and $5 \mathrm{~mm}$ in length. Prior to nitriding, all the samples were prepared metallographically. The coating bath consists of ferro titanium and pure aluminium for metallic element supplier, ammonium chloride as an activator, naphthalene for de-oxidation materials and alumina as a filler material. AISI D2 steel was pre-nitrided by gas nitriding process at $575^{\circ} \mathrm{C}$ for $8 \mathrm{~h}$. Then, TiAlN coating treatment was performed by TRD technique at $1000^{\circ} \mathrm{C}$ for $2 \mathrm{~h}$, followed by quenching in air.

$\mathrm{X}$-ray diffraction (XRD) analysis was performed on the sample surface. $\mathrm{Cu} K_{\alpha}$ radiation with a wavelength of $1.5418 \AA$ was used. The potentiodynamic polarization technique was used to evaluate the corrosion properties of the uncoated, nitrided steel and TiAlN coating, and the electrochemical impedance spectroscopy (EIS) was employed to reveal changes in the corrosion behaviour of the coating/substrate system. All the electrochemical tests were performed at $25^{\circ} \mathrm{C}$ in open-to-air $0.5 \mathrm{M} \mathrm{H}_{2} \mathrm{SO}_{4}$ aqueous solution using PCI4/750/ ZRA potentiostat-galvanostat (Gamry Instrument) system. The traditional three-electrode system was applied, where the saturated calomel electrode (SCE) acted as a reference electrode and a graphite bar as a counter electrode. The polarization curves were measured at a scan rate of $1 \mathrm{mV} / \mathrm{s}$, starting from an initial potential 
of $-0.1 \mathrm{~V}$ vs. the open circuit potential of the tested samples. Corrosion potential ( $\left.E_{\text {corr }}\right)$, corrosion current $\left(I_{\text {corr }}\right)$, anodic Tafel slope $\left(\beta_{\mathrm{a}}\right)$, cathodic Tafel slope $\left(\beta_{\mathrm{c}}\right)$ were provided after analyzed by that software. Corrosion resistance $\left(R_{\mathrm{p}}\right)$ was calculated using Eqs. (1) and (2) [13]:

$$
\begin{aligned}
& I_{\text {corr }}=B / R_{\mathrm{p}}, \\
& B=\beta_{\mathrm{a}} \beta_{\mathrm{c}} /\left[2.303\left(\beta_{\mathrm{a}}+\beta_{\mathrm{c}}\right)\right] .
\end{aligned}
$$

\section{Results and discussion}

XRD analysis of the TiAlN coated AISI D2 steel sample at $1000{ }^{\circ} \mathrm{C}$ for $2 \mathrm{~h}$ showed that the phases formed on the coated steel sample are $\mathrm{TiN}, \mathrm{AlTi}_{3} \mathrm{~N}$ and $\mathrm{Ti}_{3} \mathrm{Al}_{2} \mathrm{~N}_{2}$ phases.

Figure 1 shows the potentiodynamic polarization curves of the untreated, nitrided and the TiAlN coated AISI D2 steels tested in the $0.5 \mathrm{M} \% \mathrm{H}_{2} \mathrm{SO}_{4}$ aqueous solution. The corrosion potential $\left(E_{\text {corr }}\right)$, current density $\left(i_{\text {corr }}\right)$ and polarization resistance $\left(R_{\mathrm{p}}\right)$ obtained by Tafel calculations for uncoated, nitrided and coated steels are given in Table I. The current density value of the
TiAlN coated sample is $21.77 \mu \mathrm{A} / \mathrm{cm}^{2}$ which is much lower than that of the uncoated steel $\left(59.05 \mu \mathrm{A} / \mathrm{cm}^{2}\right)$ and nitrided steel $\left(50.68 \mu \mathrm{A} / \mathrm{cm}^{2}\right)$. In addition, the TiAlN coated sample has got the highest $E_{\text {corr }}(-403)$ and $R_{\mathrm{p}}(0.3541)$ values. These electrochemical characteristics demonstrate the capacity of the TiAlN coating for providing corrosion protection to the underlying substrate.

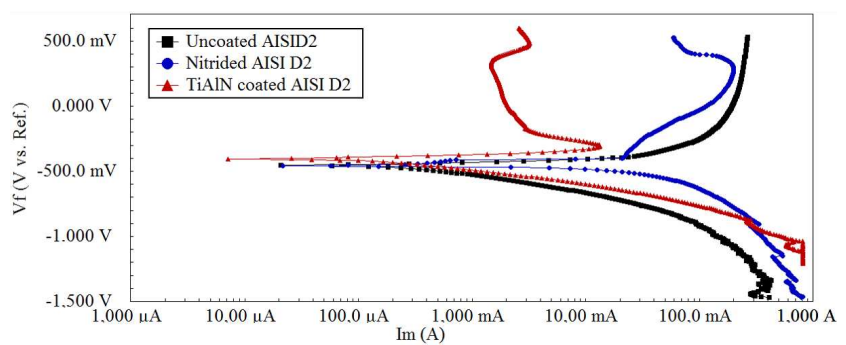

Fig. 1. Polarization curves of the uncoated, nitrided, and TiAlN coated AISI D2 steels.

Electrochemical parameters of the uncoated, nitrided and TiAlN coated AISI D2 in $\mathrm{H}_{2} \mathrm{SO}_{4}$.

\begin{tabular}{c|c|c|c|c|c|c}
\hline \hline \multirow{2}{*}{$\begin{array}{c}\text { Corrosion } \\
\text { environment }\end{array}$} & \multirow{3}{*}{ Sample } & \multicolumn{5}{|c}{ Potentiodynamic polarization parameters } \\
\cline { 3 - 7 } & $\begin{array}{c}I_{\text {corr }} \\
{\left[\mu \mathrm{A} / \mathrm{cm}^{2}\right]}\end{array}$ & $\begin{array}{c}E_{\text {corr }} \\
{[\mathrm{mV}]}\end{array}$ & $\begin{array}{c}\beta_{\mathrm{a}} \\
{\left[\times 10^{-3} \mathrm{mV}\right]}\end{array}$ & $\begin{array}{c}\beta_{\mathrm{c}} \\
{\left[\times 10^{-3} \mathrm{mV}\right]}\end{array}$ & $\begin{array}{c}R_{\mathrm{p}} \\
{\left[\times 10^{-3} \mathrm{k} \Omega / \mathrm{cm}^{2}\right]}\end{array}$ \\
\hline \multirow{3}{*}{$0.5 \mathrm{M} \mathrm{H}_{2} \mathrm{SO}_{4}$} & uncoated & 59.05 & -454 & 24 & 75 & 0.1336 \\
& nitrided & 50.68 & -462 & 60 & 31 & 0.1751 \\
& TiAlN coated & 21.77 & -403 & 26 & 56 & 0.3541
\end{tabular}

The corrosion properties of TiN and TiAlN coatings.

TABLE II

\begin{tabular}{c|c|c|c|c|c}
\hline \hline Coating/substrate & Medium & $E_{\text {corr }}[\mathrm{mV}]$ & $\begin{array}{c}I_{\text {corr }} \\
{\left[\mu \mathrm{A} / \mathrm{cm}^{2}\right]}\end{array}$ & $\begin{array}{c}R_{\mathrm{p}} \\
{\left[\mathrm{k} \Omega / \mathrm{cm}^{2}\right]}\end{array}$ & Ref. \\
\hline TiAlN/AISI D2 (present study) & $0.5 \mathrm{M} \mathrm{H}_{2} \mathrm{SO}_{4}$ & -403 & 21.77 & 0.3541 & - \\
TiAlN/AISI H13 & $0.5 \mathrm{M} \mathrm{NaCl}$ & -439 & 2.23 & 12.02 & {$[1]$} \\
TiAlN/ASTM-SA213-T-11 & $0.5 \mathrm{M} \mathrm{NaCl}$ & -441 & 1.268 & 33.73 & {$[15]$} \\
TiAlN/MB40-P40 & $0.5 \mathrm{M} \mathrm{NaCl}$ & -212 & 0.063 & 535 & {$[3]$} \\
TiAlN/1Cr11Ni2W2MoV & $0.5 \mathrm{M} \mathrm{NaCl}$ & -378 & 0.171 & - & {$[7]$} \\
TiN/AISI H13 & $0.5 \mathrm{M} \mathrm{NaCl}$ & -375 & 4.39 & 6.35 & {$[1]$} \\
TiN/MB40-P40 & $0.5 \mathrm{M} \mathrm{NaCl}$ & -349 & 0.066 & 164 & {$[3]$} \\
TiN/1Cr11Ni2W2MoV & $0.5 \mathrm{M} \mathrm{NaCl}$ & -286 & 0.335 & - & {$[7]$}
\end{tabular}

The corrosion behaviour of TiAlN may also have been affected because of the presence of $\mathrm{Al}$. It has been reported that the addition of $\mathrm{Al}$ to the transition metal nitrides improves the corrosion resistance. During the chemical attack, aluminium forms an $\mathrm{Al}_{2} \mathrm{O}_{3}$ layer on the surface of the coating, which passivates the surface and prevents the coating from further attack $[14,15]$.
It is clearly evident from the corrosion results that the TiAlN coatings exhibit superior corrosion resistance as compared to the TiN coatings as shown in Table II.

As shown in Fig. 2, the EIS data of TiAlN coated steel, nitrided and untreated steel samples are also presented as the Nyquist plot, which were comprised of real and imaginary parts of the impedance as a function of the applied 


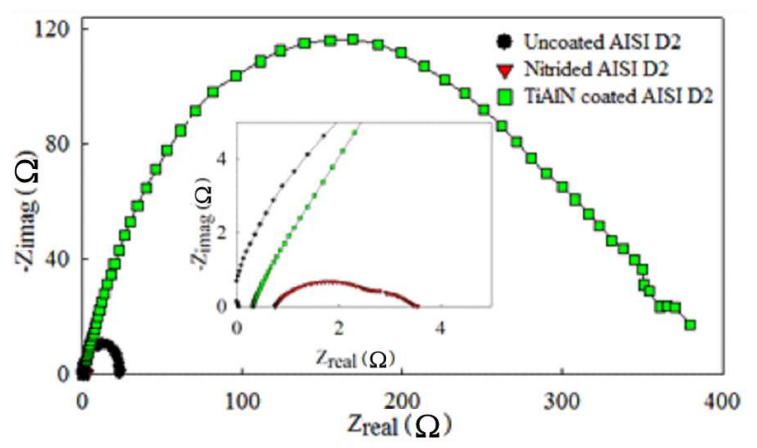

Fig. 2. Nyquist plots for EIS data of the uncoated, nitrided, and TiAlN coated AISI D2 steels.

frequency perturbation. A convenient way to evaluate the corrosion properties of the samples is to compare the diameters of the semi-circles in the Nyquist plot [16, 17]. The larger the arc diameter is, the better corrosion resistance of the sample was expected. As shown in Fig. 2, the TiAlN coated steel exhibited the larger arc diameter than that of the nitrided and untreated AISI D2 steels, and better corrosion resistance of these steels were evident.

\section{Conclusions}

TiAlN coating layer was dense and exhibits laminar microstructure with a well-defined coating/substrate interface. After coating treatment, surface hardness of coated AISI D2 has a pronounced increase compared to uncoated AISI D2. TiAlN coating is more effective to improve the surface hardness. The phases formed in the TiAlN layer are $\mathrm{TiN}, \mathrm{Ti}_{3} \mathrm{AlN}$, and $\mathrm{Ti}_{3} \mathrm{Al}_{2} \mathrm{~N}_{2}$. The above results revealed that TiAlN coating has a high corrosion resistance in acid solution.

\section{References}

[1] D. Pye, ASM International 31 (2003).

[2] R. Riedel, Handbook of ceramic hard materials, Wiley-VCH, UK 2000, p. 23.

[3] Y. Li, L. Qu, F. Wang, Corrosion Sci. 45, 1367 (2003)

[4] M. Savaşkan, Y. Taptik, M. Ürgen, Itü J./d Eng. 3, 117 (2004) (in Turkish).

[5] G.B. Gaitan, J.C. Caicedo, A.G. Balogh, S. Gottschalk, Phys. Status Solidi C 4, 4260 (2007).

[6] A. Schuler, V. Thommen, P. Reimann, P. Oelhafen, J. Vac. Sci. Technol. A 19, 922 (2001)

[7] J.F. Marco, J.R. Gancedo, M.A. Auger, O. Sanchez, J.M. Albella, Surf. Interface Anal. 37, 1082 (2005)

[8] A. Kovalev, D.L. Wainstein, G. Fox-Rabinovich, K. Yamamoto, S. Veldhius, Surf. Interface Anal. 38, 879 (2006)

[9] S. Seal, JOM 5951 (2001).

[10] A. Kimura, H. Hasegawa, K. Yamada, T. Suzuki, Surf. Coat. Technol. 120-121, 438 (1999).

[11] V. Chawla, A. Chawla, Y. Mehta, D. Puri, S.B. Sidhu, J. Austral. Ceram. Soc. 47, 48 (2011).

[12] J.L. Huang, B.Y. Shew, J. Am. Ceram. Soc. 82, 696 (1999).

[13] R. Baboian, Corrosion Test and Standards, ASTM, Baltimore 2005, p. 109.

[14] H.C. Barshilia, N. Selvakumar, B. Deepthi, K.S. Rajam, Surf. Coat. Technol. 201, 2193 (2006)

[15] H.C. Barshilia, B. Deepthi, K.S. Rajam, K.W. Bhatti, S. Chaudhary, J. Vac. Sci. Technol. A 27, 1 (2009)

[16] L. Bai, X. Zhu, J. Xiao, J. He, Surf. Coat. Technol. 201, 5257 (2007)

[17] C.H. Lin, J.G. Duh, Surf. Coat. Technol. 204, 784 (2009). 